Wild Religion 



\section{Wild Religion}

Tracking the Sacred in South Africa

\section{David Chidester}

\section{甲}

UNIVERSITY OF CALIFORNIA PRESS

Berkeley • Los Angeles • London 
University of California Press, one of the most distinguished university presses in the United States, enriches lives around the world by advancing scholarship in the humanities, social sciences, and natural sciences. Its activities are supported by the UC Press Foundation and by philanthropic contributions from individuals and institutions. For more information, visit www.ucpress.edu.

University of California Press

Berkeley and Los Angeles, California

University of California Press, Ltd.

London, England

(C) 2012 by The Regents of the University of California

Library of Congress Cataloging-in-Publication Data

Chidester, David.

Wild religion : tracking the sacred in South Africa / David Chidester.

p. $\mathrm{cm}$.

Includes bibliographical references and index.

ISBN 978-0-520-27307-8 (cloth : alk. paper) ISBN 978-0-520-27308-5 (pbk. : alk. paper)

I. South Africa--Religion. 2. Religion and sociology-South Africa. 3. Cults-South Africa. 4. Nativistic movements-South Africa. 5. Cultural pluralism-South Africa. 6. South Africa-Religious life and customs. I. Title.

BL2470.S6C47 20I2

$200.968-\mathrm{dc} 23$

2011042261

Manufactured in the United States of America

$\begin{array}{lllllllll}20 & \text { I9 } & \text { I8 } & \text { I7 } & \text { I6 } & \text { I5 } & \text { I4 } & \text { I3 } & \text { I2 }\end{array}$

In keeping with a commitment to support environmentally responsible and sustainable printing practices, UC Press has printed this book on Rolland Enviroı00, a I00\% post-consumer fiber paper that is FSC certified, deinked, processed chlorine-free, and manufactured with renewable biogas energy. It is acid-free and EcoLogo certified. 